\title{
Characteristics and clinical outcomes of living renal donors in Hong Kong
}

\author{
YL Hong, CH Yee, CB Leung, Jeremy YC Teoh, Bonnie CH Kwan, Philip KT Li, Simon SM Hou, CF Ng *
}

\section{A B S T R A C T}

Introduction: In Asia, few reports are available on the outcomes for living renal donors. We report the short- and long-term clinical outcomes of individuals following living donor nephrectomy in Hong Kong.

Methods: We retrospectively reviewed the characteristics and clinical outcomes of all living renal donors who underwent surgery from January 1990 to December 2015 at a teaching hospital in Hong Kong. Information was obtained from hospital records and territory-wide electronic patient

Results: During the study period, 83 individuals underwent donor nephrectomy. The mean $( \pm$ standard deviation) follow-up time was $12.0 \pm 8.3$ years, and the mean age at nephrectomy was $37.3 \pm$ 10.0 years. A total of 44 (53.0\%), four (4.8\%), and 35 (42.2\%) donors underwent living donor nephrectomy via an open, hand-port assisted laparoscopic, and laparoscopic approach, respectively. The overall incidence of complications was $36.6 \%$, with most being grade 1 or 2 . There were three $(9.4 \%)$ grade 3a complications; all were related to open donor nephrectomy. The mean glomerular filtration rate was $96.0 \pm 17.5 \mathrm{~mL} / \mathrm{min} / 1.73 \mathrm{~m}^{2}$ at baseline and significantly lower at $66.8 \pm 13.5 \mathrm{~mL} / \mathrm{min} / 1.73 \mathrm{~m}^{2}$ at first annual follow-up $(\mathrm{P}<0.01)$. The latest mean

baseline. No donor died or developed renal failure. records.

Of the donors, 14 (18.2\%) developed hypertension, two $(2.6 \%)$ had diabetes mellitus, and three $(4.0 \%)$ had experienced proteinuria.

Conclusion: The overall perioperative outcomes are good, with very few serious complications. The introduction of a laparoscopic approach has decreased perioperative blood loss and also shortened hospital stay. Long-term kidney function is satisfactory and no patients developed end-stage renal disease. The incidences of new-onset medical diseases and pregnancy-related complications were also low.
Hong Kong Med J 2018;24:11-7
DOI: $10.12809 / \mathrm{hkmj} 176820$
${ }^{1}$ YL Hong, MSc
${ }^{1} \mathrm{CH}$ Yee, FHKAM (Surgery)
${ }^{2}$ CB Leung, FHKAM (Surgery)
${ }^{1}$ JYC Teoh, FHKAM (Surgery)
${ }^{2}$ BCH Kwan, FHKAM (Medicine)
${ }^{2}$ PKT Li, FHKAM (Medicine)
SSM Hou, FHKAM (Surgery)
${ }^{1} \mathrm{CF} \mathrm{Ng}$ *, FHKAM (Surgery)
${ }^{1}$ SH Ho Urology Centre, Department of Surgery
2 Division of Nephrology, Department of Medicine and Therapeutics
Prince of Wales Hospital, The Chinese University of Hong Kong, Shatin, Hong Kong
* Corresponding author: ngcf@surgery.cuhk.edu.hk

New knowledge added by this study

- The overall perioperative outcomes are good, with very few serious complications, among living renal donors. The introduction of a laparoscopic approach has decreased perioperative blood loss and also shortened hospital stay.

- Long-term kidney function was satisfactory and no patients developed end-stage renal disease (ESRD).

- The incidences of new-onset medical disease and pregnancy-related complications were also low.

Implications for clinical practice or policy

- Medical practitioners should encourage relatives of patients with ESRD to consider the possibility of kidney donation.

\section{Introduction}

Chronic kidney disease (CKD) is the progressive loss of kidney function over a period of time. Endstage renal disease (ESRD) is the final stage of CKD. Patients with ESRD require renal replacement therapy that includes haemodialysis, peritoneal dialysis, and renal transplantation.

Currently, there are approximately 7000 patients on various forms of renal replacement therapy being cared for in the public sector in Hong Kong. As of 31 December 2016, 2047 patients were on the renal transplant waiting list. Nonetheless, between 2007 and 2016, only 58 to 87 cadaveric renal transplants were performed in Hong Kong each year. ${ }^{1}$ With the long waiting list and low number of cadaveric kidneys available, living donor renal transplant is the only possible alternative. It offers advantages over other renal replacement 


\section{香港活體捐腎者的特徵及臨床結果}

\section{匡若琳、余知行、梁誌邦、張源津、關清霞、李錦滔、 侯仕明、吳志輝}

引言：亞洲只有少數關於活體捐腎者臨床結果的報導。本文報告香港 捐腎者的長短期臨床結果。

方法：回顧分析 1990年1月至2015年12月期間, 在香港一所教學醫院 內接受手術的所有捐腎者的特點和臨床結果。資料來自醫院紀錄及全 港電子醫療紀錄。

結果 : 研究期間共 83 名捐腎者接受腎切除術。平均 ( \pm 標準差 $)$ 隨訪 時間為 $12.0 \pm 8.3$ 年, 捐腎者接受腎切除術時的平均年齡為 $37.3 \pm 10.0$ 歲。他們進行腎切除術的方式為開放式 44 例（53.0\%）, 手助式腹 腔鏡 4例（4.8\%），以及腹腔鏡手術35例（42.2\%）。總併發症發 生率為 $36.6 \%$, 大部分屬 1 級或 2 級; 有3名 (9.4\%) 捐腎者的併發 症屬 $3 \mathrm{a}$ 級, 均與開放式手術有關。平均腎小球濾過率方面, 基線 為 $96.0 \pm 17.5 \mathrm{~mL} / \mathrm{min} / 1.73 \mathrm{~m}^{2}$, 首次隨訪時為 $66.8 \pm 13.5 \mathrm{~mL} / \mathrm{min} /$ $1.73 \mathrm{~m}^{2}$ 的顯著較低水平 $(\mathrm{P}<0.01) \circ$ 最後一次的平均腎小球濾過率 為基線的 $75.6 \% \pm 15.1 \%$ 。沒有捐腎者死亡或出現腎衰竭。捐腎者中有 14 人 $(18.2 \%)$ 患有高血壓, 2 人 $(2.6 \%)$ 有糖尿病, 3 人 $(4.0 \%)$ 有 蛋白尿。

結論：捐腎者的圍手術期結果良好, 只有少數出現嚴重併發症。引入 腹腔鏡手術減少了圍手術期失血, 並縮短了住院時間。捐腎者的長期 腎功能令人滿意, 沒有患者出現末期腎病。新出現的內科疾病和妊娠 相關併發症的發生率也偏低。 therapies, as it provides better long-term results, shortens the waiting time for an organ, lowers the risk of complications or rejection, and provides better quality of life after recovery. Despite these advantages, only seven to 15 living donor transplants were performed each year between 2007 and 2015 at the hospitals of the Hong Kong Hospital Authority. ${ }^{1}$

One of the major fears of an individual who is considering living organ donation concerns possible clinical outcomes. Although studies show that living donors have a similar to or better life expectancy than the general population, they are nevertheless at increased risk of developing ESRD, hypertension, gestational hypertension, and pre-eclampsia..$^{2-4}$

In Hong Kong, few reports on the perioperative, short-term, and long-term clinical outcomes are available, especially those related to the minimally invasive surgical approach now employed for donor nephrectomy. This study reports our observation of characteristics of donors, and the short- and long-term clinical outcomes following living donor nephrectomy in Hong Kong.

\section{Methods}

\section{Study design}

We retrospectively reviewed the characteristics and short- and long-term clinical outcomes of all patients who underwent living donor nephrectomy at the Prince of Wales Hospital in Hong Kong between January 1990 and December 2015. Information was obtained from the Clinical Management System that includes the majority of electronic patient recordsincluding consultation histories, operation records, radiology results, laboratory results, and medication records-collected and filed under the Hospital Authority since 2000. Medical records before 2000 and pregnancy-related information were reviewed manually by formally trained medical students and cross-checked by a urologist, and retrieved from the medical records of the involved patients.

The study was conducted in accordance with the principles outlined in the Declaration of Helsinki, and approved by the Joint Chinese University of Hong Kong-New Territories East Cluster Clinical Research Ethics Committee, with the requirement of patient informed consent waived because of its retrospective nature.

\section{Study measures}

Baseline demographics including sex, age at donation, ethnicity, relationship with recipient, diabetes mellitus status, hypertension status, body mass index, and serum creatinine level were obtained. Glomerular filtration rate (GFR) was derived from the serum creatinine level using a modified equation from the Modification of Diet in Renal Disease (MDRD) study. ${ }^{5}$ Operation details, including surgical approach, laterality of donated kidney, operating time, warm ischaemia time, blood loss, and need for transfusion were retrieved.

Short-term complications within 30 days of surgery were classified according to the ClavienDindo classification of surgical complications. ${ }^{6}$ Longterm outcomes were also assessed, with particular reference to development of hypertension, diabetes mellitus, renal stones, proteinuria, and renal failure. Serial changes in GFR were also assessed.

For female donors, pregnancy-related variables were recorded and included any pregnancy after surgery, records of pregnancyrelated hydronephrosis, pregnancy-related urinary tract infection, pre-eclampsia, gestational diabetes mellitus, gestational hypertension, and any fetal loss.

\section{Statistical analyses}

All statistical analyses were performed using the SPSS (Windows version 23.0; IBM Corp, Armonk [NY], United States). Categorical variables were presented in counts and percentages while continuous variables were presented as mean \pm standard deviation. Outcomes following open and laparoscopic techniques were compared by Chi squared test or Fisher's exact test for categorical variables, and independent $t$ test or Mann-Whitney 
$U$ test for continuous variables. Paired $t$ test or Wilcoxon rank sum test, whichever was appropriate, was used to evaluate the pre- and post-difference in GFR. A P value of $<0.05$ was considered statistically significant. Missing data were excluded from analysis.

\section{Results}

\section{Donor characteristics}

Between 1 January 1990 and 31 December 2015, a total of 83 donors underwent unilateral nephrectomy at the Prince of Wales Hospital. In one donor, records could not be traced, with only information about the sex, age at nephrectomy, and type of surgical technique.

Of the 83 donors, 56 (67.5\%) were female. The mean age at nephrectomy was $37.3 \pm 10.0$ years. The majority were Chinese (97.6\%) and a first-degree relative of the recipient $(79.3 \%)$. None had hypertension or diabetes mellitus. The mean preoperative GFR was $96.0 \pm 17.5 \mathrm{~mL} / \mathrm{min} / 1.73 \mathrm{~m}^{2}$. Nine $(11.0 \%)$ donors had thalassaemia trait, four (4.9\%) had hepatitis B, and two (2.4\%) had asthma (Table 1).

TABLE I. Baseline characteristics of kidney donors

\begin{tabular}{|c|c|}
\hline Baseline characteristic & $\begin{array}{l}\text { No. }(\%) \text { of donors } \\
\text { or mean } \pm \text { SD }\end{array}$ \\
\hline \multicolumn{2}{|l|}{ Sex, $n=83$} \\
\hline Male & $27(32.5)$ \\
\hline Female & $56(67.5)$ \\
\hline Age at nephrectomy (years), $n=83$ & $37.3 \pm 10.0$ \\
\hline \multicolumn{2}{|l|}{ Ethnicity, $\mathrm{n}=82$} \\
\hline Chinese & $80(97.6)$ \\
\hline Indonesian & $1(1.2)$ \\
\hline Filipino & $1(1.2)$ \\
\hline \multicolumn{2}{|l|}{ Relationship with recipient, $\mathrm{n}=82$} \\
\hline First-degree relative & $65(79.3)$ \\
\hline Sibling & $49(59.8)$ \\
\hline Parent to child & $8(9.8)$ \\
\hline Child to parent & $8(9.8)$ \\
\hline Spouse & $15(18.3)$ \\
\hline Second-/third-degree relative & $2(2.4)$ \\
\hline Baseline BMI $\left(\mathrm{kg} / \mathrm{m}^{2}\right), \mathrm{n}=37$ & $23.1 \pm 2.5$ \\
\hline Baseline serum $\mathrm{Cr}(\mu \mathrm{mol} / \mathrm{L}), \mathrm{n}=76$ & $74.2 \pm 15.2$ \\
\hline Baseline GFR $\left(\mathrm{mL} / \mathrm{min} / 1.73 \mathrm{~m}^{2}\right), \mathrm{n}=76$ & $96.0 \pm 17.5$ \\
\hline \multicolumn{2}{|l|}{ Other health condition, $\mathrm{n}=82$} \\
\hline With thalassaemia trait & $9(11.0)$ \\
\hline Hepatitis B carrier & $4(4.9)$ \\
\hline Asthma & $2(2.4)$ \\
\hline
\end{tabular}

Abbreviations: $\mathrm{BMI}=$ body mass index; $\mathrm{Cr}=$ creatinine; $\mathrm{GFR}=$ glomerular filtration rate; $\mathrm{SD}=$ standard deviation

\section{Operation details and short-term outcomes}

Around half ( $n=44,53.0 \%)$ of the donors underwent open living donor nephrectomy, as this was the only technique used at our centre until 2002. After 2002, a hand-port assisted laparoscopic approach $(n=4,4.8 \%)$ and later a laparoscopic approach $(n=35$, $42.2 \%)$ were adopted. In most instances, the left kidney was donated $(n=77,93.9 \%)$ [Table 2].

Comparing laparoscopic or hand-port assisted laparoscopic living donor nephrectomy (LDN) with open donor nephrectomy (ODN), LDN was associated significantly with longer warm ischaemia time $(309.0 \pm 113.0 \mathrm{~s}$ vs $62.0 \pm 17.9 \mathrm{~s} ; \mathrm{P}<0.01)$, less blood loss $(55.3 \pm 33.7 \mathrm{~mL}$ vs $532.2 \pm 270.0 \mathrm{~mL}$; $\mathrm{P}<0.01)$, and shorter hospital stay $(5.7 \pm 2.0$ days vs $8.1 \pm 1.9$ days; $\mathrm{P}<0.01)$. In addition, $\mathrm{LDN}$ was associated significantly with more short-term complications $(53.8 \%$ vs $20.9 \% ; \mathrm{P}<0.01)$. The most commonly experienced complication was epigastric pain/nausea and vomiting $(n=18,56.3 \%)$, followed by fever requiring medication $(n=4,12.5 \%)$. Most complications were grade 1 on the Clavien-Dindo classification scale $(n=16,50.0 \%)$, only three $(9.4 \%)$ were grade $3 \mathrm{a}$ and all were related to ODN. The grade $3 \mathrm{a}$ complications were wound dehiscence that required a second operation for re-suturing, persistent pancreatic fluid discharge that required insertion of a pancreatic stent, and pneumothorax with chest drain inserted.

\section{Long-term outcomes}

The mean follow-up time was $12.0 \pm 8.3$ years. The mean GFR was $96.0 \pm 17.5 \mathrm{~mL} / \mathrm{min} / 1.73 \mathrm{~m}^{2}$ at baseline and it dropped significantly to $66.8 \pm 13.5$ $\mathrm{mL} / \mathrm{min} / 1.73 \mathrm{~m}^{2}$ at 1 -year follow-up $(\mathrm{P}<0.01)$. The GFR then gradually improved until 8 years after surgery and became stable (Fig). Of 73 living donors with at least one follow-up (mean follow-up time, $12.0 \pm 8.2$ years) and baseline serum creatinine level available, the latest GFR was $75.6 \% \pm 15.1 \%$ of baseline GFR with the mean latest GFR being $71.3 \pm 14.2$ $\mathrm{mL} / \mathrm{min} / 1.73 \mathrm{~m}^{2}$. The mean GFR was $70.4 \% \pm 12.3 \%$ of baseline level 1 year after surgery. Comparison of latest GFR with that 1 year after surgery revealed that it was stable ( $\pm 10 \%$ change) in $23(39.0 \%)$ of 59 patients and higher (>10\% increment) in 29 (49.2\%) patients. None of the donors had died or developed ESRD. Fourteen (18.2\%) donors developed hypertension, two $(2.6 \%)$ had diabetes mellitus, and three $(4.0 \%)$ had experienced proteinuria (Table 3$).$

\section{Pregnancy-related complications}

Of 56 female donors, 11 (19.6\%) became pregnant after kidney donation: 17 pregnancies were reported. None of the pregnant donors experienced gestational hydronephrosis or gestational hypertension. Three donors each had gestational diabetes mellitus, pre- 
TABLE 2. Comparison of operation details and short-term outcomes by operation techniques

\begin{tabular}{|c|c|c|c|c|c|c|c|}
\hline & \multicolumn{2}{|c|}{ Total } & \multicolumn{2}{|c|}{ Open technique } & \multicolumn{2}{|c|}{$\begin{array}{l}\text { Laparoscopic or hand-port } \\
\text { assisted laparoscopic }\end{array}$} & \multirow[t]{2}{*}{$P$ value } \\
\hline & $\begin{array}{l}\text { No. of } \\
\text { donors }\end{array}$ & Data* & $\begin{array}{l}\text { No. of } \\
\text { donors }\end{array}$ & Data* & $\begin{array}{l}\text { No. of } \\
\text { donors }\end{array}$ & Data* & \\
\hline Left or right kidney & 82 & & 43 & & 39 & & 0.362 \\
\hline Left & & 77 (93.9) & & $39(90.7)$ & & $38(97.4)$ & \\
\hline Right & & $5(6.1)$ & & $4(9.3)$ & & $1(2.6)$ & \\
\hline Operating time (hours) & 40 & $3.5(0.9)$ & 3 & $3.0(0.7)$ & 37 & $3.6(0.9)$ & 0.354 \\
\hline Warm ischaemia time (s) & 39 & $277.4 \pm 134.6$ & 5 & $62.0 \pm 17.9$ & 34 & $309.0 \pm 113.0$ & $<0.01$ \\
\hline Blood loss (mL) & 29 & $137.5 \pm 212.1$ & 5 & $532.2 \pm 270.0$ & 24 & $55.3 \pm 33.7$ & $<0.01$ \\
\hline In-patient hospital stay (days) & 79 & $6.9 \pm 2.3$ & 40 & $8.1 \pm 1.9$ & 39 & $5.7 \pm 2.0$ & $<0.01$ \\
\hline Complication & 82 & & 43 & & 39 & & $<0.01$ \\
\hline Yes & & $30(36.6)$ & & 9 (20.9) & & $21(53.8)$ & \\
\hline No & & $52(63.4)$ & & $34(79.1)$ & & $18(46.2)$ & \\
\hline Complication by episode: type & 32 & & 10 & & 22 & & 0.217 \\
\hline Epigastric pain/nausea and vomiting & & $18(56.3)$ & & $4(40.0)$ & & $14(63.6)$ & \\
\hline Fever (treated with medication) & & $4(12.5)$ & & 0 & & $4(18.2)$ & \\
\hline Leak & & $2(6.3)$ & & $1(10.0)$ & & $1(4.5)$ & \\
\hline Bleeding & & $2(6.3)$ & & $1(10.0)$ & & $1(4.5)$ & \\
\hline Infection & & $2(6.3)$ & & $1(10.0)$ & & $1(4.5)$ & \\
\hline Other & & $4(12.5)$ & & $3(30.0)$ & & $1(4.5)$ & \\
\hline Complication by episode $\dagger$ & 32 & & 10 & & 22 & & 0.021 \\
\hline Grade 1 & & $16(50.0)$ & & $3(30.0)$ & & $13(59.1)$ & \\
\hline Grade 2 & & $13(40.6)$ & & $4(40.0)$ & & $9(40.9)$ & \\
\hline Grade 3a & & $3(9.4)$ & & $3(30.0)$ & & 0 & \\
\hline Total No. of complications & 82 & $0.4 \pm 0.5$ & 43 & $0.2 \pm 0.5$ & 39 & $0.6 \pm 0.6$ & 0.005 \\
\hline Latest GFR (mL/min/1.73 $\left.\mathrm{m}^{2}\right)$ & 77 & $71.3 \pm 14.2$ & 40 & $74.7 \pm 14.5$ & 37 & $65.6 \pm 12.9$ & 0.025 \\
\hline
\end{tabular}

Abbreviation: GFR = glomerular filtration rate

* Data are shown as No. (\%) or mean \pm standard deviation

† According to Clavien-Dindo classification scale

eclampsia, and post-delivery urinary tract infection. Two donors had experienced fetal loss, one in the first trimester and another one at an unknown gestational age (Table 4).

\section{Discussion}

Postoperative morbidity and mortality are the prime concerns when making a decision about kidney donation. Our results confirm that living donor nephrectomy is a relatively safe procedure, with a low incidence of major complications and mortality. In addition, the incidence of developing any other major disease was not particularly high in our series. This form of renal replacement therapy should be further promoted in Hong Kong to benefit more people with ESRD.
Results from previous studies have shown that living renal donors have a similar to or better life expectancy than the general population. ${ }^{7-10}$ Mjøen et $\mathrm{al}^{11}$ however, reported that compared with healthy matched individuals, living renal donors had an increased risk of death. In Hong Kong, Chu et $\mathrm{al}^{12}$ reported one death related to multiple myeloma among 95 living renal donors with active follow-up and a mean follow-up period of 13.4 years. There were no deaths recorded in our study with a mean follow-up of 12 years.

Long-term renal function is another major concern of renal donors. Our results revealed that 1 year after living donor nephrectomy, the mean GFR of the kidney donors dropped significantly from $96.0 \pm 17.5 \mathrm{~mL} / \mathrm{min} / 1.73 \mathrm{~m}^{2}$ at baseline to $66.8 \pm 13.5 \mathrm{~mL} / \mathrm{min} / 1.73 \mathrm{~m}^{2}$. Nonetheless, it then 


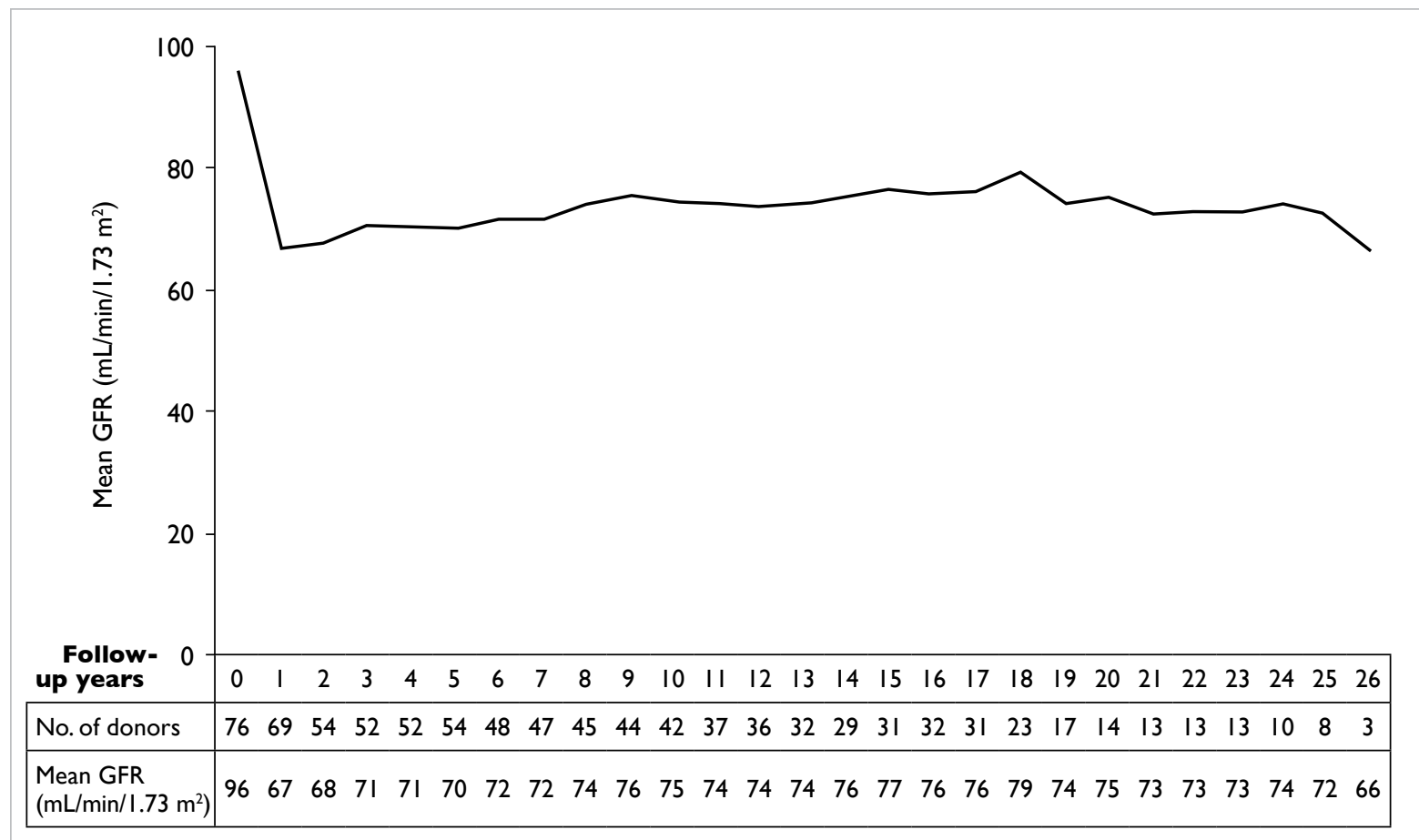

FIG. The annual mean glomerular filtration rate (GFR) after surgery

gradually improved. This is probably partly related to the adaptation of the remaining kidney with hyperfiltration. From our series, the mean GFR was $70.4 \%$ $\pm 12.3 \%$ of baseline level 1 year after surgery but improved to $75.6 \% \pm 15.1 \%$ of baseline level at the last follow-up. In the majority (88.2\%) of donors, the last available GFR was static or higher than that 1 year after donation. This is comparable with the report of Rook et $\mathrm{al}^{13}$ in which GFR usually reached $64 \% \pm 7 \%$ of the pre-donation level 1 year after donation.

Despite these changes in GFR, ESRD in renal donors is very rare, with an incidence of less than $0.5 \%$ in 15 years after donation. ${ }^{11,14,15}$ Ibrahim et $\mathrm{al}^{8}$ reported that survival and risk of ESRD in kidney donors appeared to be similar to those in the general population. Our study and that of Chu et $\mathrm{al}^{12}$ observed no ESRD in local kidney donors.

The effect of kidney donation on the development of hypertension is controversial. Although reports suggest that the incidence of hypertension among kidney donors increases, ${ }^{16-19}$ others have not confirmed this observation. ${ }^{20-24}$ In Hong Kong, the prevalence of hypertension in the general population was $12.6 \%$ in $2014,{ }^{25}$ which is lower than our reported figure of $18.2 \%$. With the progression of time after surgery, however, the prevalence of hypertension among living donors is expected to increase as age is a known influence in hypertension. Without a comparable control group, we cannot conclude if there is any actual discrepancy in the prevalence of hypertension among living
TABLE 3. Long-term outcomes for kidney donors

\begin{tabular}{|c|c|c|}
\hline & $\begin{array}{l}\text { No. of donors with } \\
\text { data available }\end{array}$ & Data* \\
\hline Follow-up (years) & 79 & $12.0 \pm 8.3$ \\
\hline Latest stones & 81 & \\
\hline Yes & & 0 \\
\hline No & & $17(21.0)$ \\
\hline Investigation not done after surgery & & $64(79.0)$ \\
\hline Latest hypertension & 77 & \\
\hline Yes & & $14(18.2)$ \\
\hline No & & $63(81.8)$ \\
\hline Latest diabetes mellitus & 76 & \\
\hline Yes & & $2(2.6)$ \\
\hline No & & $74(97.4)$ \\
\hline Renal failure & 79 & \\
\hline Yes & & 0 \\
\hline No & & $79(100)$ \\
\hline Latest proteinuria & 75 & \\
\hline Yes & & $3(4.0)$ \\
\hline No & & $72(96.0)$ \\
\hline
\end{tabular}

* Data are shown as No. (\%) or mean \pm standard deviation

donors compared with the general population.

Young female potential donors may have concerns about the impact of kidney donation on 
TABLE 4. Pregnancy-related complications

\begin{tabular}{|c|c|}
\hline Pregnancy after kidney donation & $\begin{array}{c}\text { or No. (\%) of } \\
\text { donors }\end{array}$ \\
\hline Yes & 56 \\
\hline No & $11(19.6)$ \\
\hline Hydronephrosis in pregnancy & $45(80.4)$ \\
\hline Yes & 9 \\
\hline No & 0 \\
\hline Pregnancy-related urinary tract infection & $9(100)$ \\
\hline Yes & 9 \\
\hline No & $1(11.1)$ \\
\hline Pre-eclampsia & $8(88.9)$ \\
\hline Yes & 9 \\
\hline No & $1(11.1)$ \\
\hline Gestational diabetes mellitus & $8(88.9)$ \\
\hline Yes & 10 \\
\hline No & $1(10.0)$ \\
\hline Gestational hypertension & $9(90.0)$ \\
\hline Yes & 9 \\
\hline No & 0 \\
\hline Fetal loss & $9(100)$ \\
\hline Yes & 9 \\
\hline & $2(22.2)$ \\
\hline
\end{tabular}

any future pregnancy. Garg et $\mathrm{al}^{4}$ reported that gestational hypertension or pre-eclampsia was more common among living donors than non-donors. Although our study showed an alarmingly high percentage $(11 \%)$ of pre-eclampsia and absence of gestational hypertension, the small sample size (11 donors reported one or more pregnancies) undermines the ability to infer the actual percentage.

Perioperative complications may also deter potential living donors. Based on the US data, Lentine et $\mathrm{al}^{26}$ reported that $16.8 \%$ of donors experience a perioperative complication; most commonly gastrointestinal (4.4\%). Our study showed a higher complication rate of $36.6 \%$, with epigastric pain or nausea and vomiting being the major complication (56.3\%). We further examined the techniques used and established that the complication rates of $20.9 \%$ or $53.8 \%$ respectively in donors who underwent ODN or LDN were significantly different $(\mathrm{P}<0.01)$. Despite the above mean complication rates, all complications of LDN were mild and of grade 1 or 2 according to the Clavien-Dindo classification, while three patients who underwent ODN had grade 3a complications. This is contrary to the majority of previous findings that suggest a lower perioperative complication rate for LDN and increased risk of more serious complications than during an ODN, ${ }^{27}$ although other indicators such as longer warm ischaemia time, less blood loss, and shorter hospital stays were still in line with previous findings. Further analysis of the differences between our local data and those of previous studies is warranted.

This study has several limitations. First, this was a retrospective study and the total number of living donors was restricted. Second, data quality could not be controlled and some data were incomplete, in particular for the obstetric records at other hospitals. Some data were also lost either because records were too old and pre-dated the electronic system or donors were no longer followed up at our centre. The oldest record included in the study was from 1990. At that time, record keeping was not always accurate, resulting in some baseline records from the early 1990s being missing. For example, the baseline GFR level of seven (8.4\%) patients was not found, and might have affected the overall data quality as well as the analysis and conclusion. Third, although the urologist endeavoured to ensure accurate data entry, initial interpretation of the raw records was by medical students so certain inaccuracies might have occurred. Lastly, it is known that GFR might be underestimated when derived from the MDRD equation.

\section{Conclusion}

Living donor kidney transplantation is an important approach to improve the quality of life of patients with ESRD. Good short- and long-term outcome for kidney donors is important for promoting kidney donation. Our results suggest that the overall perioperative outcomes are good, with only very few serious (grade III) complications after surgery, occurring following an open approach. Long-term kidney function of donors was satisfactory and no patients developed ESRD. Although we had no control arm in our study, the overall incidences of new-onset medical diseases and pregnancy-related complications were low. The introduction of a laparoscopic approach for kidney harvesting has helped to decrease blood loss during surgery and also shorten hospital stay. Based on this encouraging result, relatives of patients with ESRD should be encouraged to consider the possibility of kidney donation.

\section{Acknowledgements}

Sincere thanks are given to Ms Karen Man-ting Chuk, Ms Tracy Lok-sze Chiu, Mr Wing-tung Leung, and $\mathrm{Mr} \mathrm{On}$-wa $\mathrm{Ng}$ for assisting with the data collection. 


\section{Declaration}

All authors have disclosed no conflicts of interest.

\section{References}

1. Statistics (Milestones of Hong Kong organ transplantation): organ donation. Available from: http://www.organdonation. gov.hk/eng/statistics.html. Accessed 27 Dec 2017.

2. Reese PP, Boudville N, Garg AX. Living kidney donation: outcomes, ethics, and uncertainty. Lancet 2015;385:200313.

3. Delanaye P, Weekers L, Dubois BE, et al. Outcome of the living kidney donor. Nephrol Dial Transplant 2012;27:4150.

4. Garg AX, Nevis IF, Mcarthur E, et al. Gestational hypertension and preeclampsia in living kidney donors. $\mathrm{N}$ Engl J Med 2015;372:124-33.

5. Levey AS, Greene T, Kusek JW, Beck GJ. A simplified equation to predict glomerular filtration rate from serum creatinine. J Am Soc Nephrol 2000;11:155A0828.

6. Dindo D, Demartines N, Clavien PA. Classification of surgical complications: a new proposal with evaluation in a cohort of 6336 patients and results of a survey. Ann Surg 2004;240:205-13.

7. Segev DL, Muzaale AD, Caffo BS, et al. Perioperative mortality and long-term survival following live kidney donation. JAMA 2010;303:959-66.

8. Ibrahim HN, Foley R, Tan L, et al. Long-term consequences of kidney donation. N Engl J Med 2009;360:459-69.

9. Okamoto M, Akioka K, Nobori S, et al. Short- and longterm donor outcomes after kidney donation: analysis of 601 cases over a 35-year period at Japanese single center. Transplantation 2009;87:419-23.

10. Garg AX, Meirambayeva A, Huang A, et al. Cardiovascular disease in kidney donors: matched cohort study. BMJ 2012;344:e1203.

11. Mjøen G, Hallan S, Hartmann A, et al. Long-term risks for kidney donors. Kidney Int 2014;86:162-7.

12. Chu KH, Poon CK, Lam CM, et al. Long-term outcomes of living kidney donors: a single centre experience of 29 years. Nephrology (Carlton) 2012;17:85-8.

13. Rook M, Hofker HS, van Son WJ, Homan van der Heide JJ, Ploeg RJ, Navis GJ. Predictive capacity of pre-donation GFR and renal reserve capacity for donor renal function after living kidney donation. Am J Transplant 2006;6:16539.

14. Muzaale AD, Massie AB, Wainwright J, McBride MA,
Wang M, Segev DL. Long-term risk of ESRD attributable to live kidney donation: matching with healthy non-donors. Am J Transplant 2013;13:204-5.

15. Fehrman-Ekholm I, Nordén G, Lennerling A, et al. Incidence of end-stage renal disease among live kidney donors. Transplantation 2006;82:1646-8.

16. Kasiske BL, Ma JZ, Louis TA, Swan SK. Long-term effects of reduced renal mass in humans. Kidney Int 1995;48:8149.

17. Gossmann J, Wilhelm A, Kachel HG, et al. Long-term consequences of live kidney donation follow-up in $93 \%$ of living kidney donors in a single transplant center. Am J Transplant 2005;5:2417-24.

18. Garg AX, Prasad GV, Thiessen-Philbrook HR, et al. Cardiovascular disease and hypertension risk in living kidney donors: an analysis of health administrative data in Ontario, Canada. Transplantation 2008;86:399-406.

19. Doshi MD, Goggins MO, Li L, Garg AX. Medical outcomes in African American live kidney donors: a matched cohort study. Am J Transplant 2012;13:111-8.

20. Fehrman-Ekholm I, Dunér F, Brink B, Tydén G, Elinder CG. No evidence of accelerated loss of kidney function in living kidney donors: results from a cross-sectional followup. Transplantation 2001;72:444-9.

21. Macdonald D, Kukla AK, Ake S, et al. Medical outcomes of adolescent live kidney donors. Pediatric Transplant 2014;18:336-41.

22. Janki S, Klop KW, Dooper IM, Weimar W, Ijzermans JN, Kok NF. More than a decade after live donor nephrectomy: a prospective cohort study. Transpl Int 2015;28:1268-75.

23. Tavakol MM, Vincenti FG, Assadi H, et al. Long-term renal function and cardiovascular disease risk in obese kidney donors. Clin J Am Soc Nephrol 2009;4:1230-8.

24. El-Agroudy AE, Wafa EW, Sabry AA, et al. The health of elderly living kidney donors after donation. Ann Transplant 2009;14:13-9.

25. Census and Statistics Department, Hong Kong SAR Government. Thematic Household Survey Report No. 58. Available from: http://www.statistics.gov.hk/pub/ B11302582015XXXXB0100.pdf. Accessed 28 Oct 2016.

26. Lentine KL, Lam NN, Axelrod D, et al. Perioperative complications after living kidney donation: a national study. Am J Transplant 2016;16:1848-57.

27. Fonouni H, Mehrabi A, Golriz M, et al. Comparison of the laparoscopic versus open live donor nephrectomy: an overview of surgical complications and outcome. Langenbecks Arch Surg 2014;399:543-51. 